\title{
Influence of organization structure on design and implementation of effective planning and control systems
}

\author{
M.D. Groch
}

\begin{abstract}
Aspects of organizational structure that influence the design and implementation of planning and control systems are discussed. The role of organization structure, planning systems and control systems in organizations is described, showing the interaction of each with the others. The spectrum of planning and control, in terms of Anthony's model, interfaces between organization structure, strategic planning, management control and operational control, as well as structural determinants of specialization, responsibility, management hierarchy, authority and financial systems are analysed, describing how each dictates in some way the nature of planning and control systems. Organizational growth and its effects on required changes to organizational structure and planning and control systems are described, and mention is made of the sterile nature of organization structure and planning and control systems and of the effects of human behaviour on organizational performance.
\end{abstract}

S. Afr. J. Bus. Mngmnt. 1979, 10:1-10

Aspekte van organisasiestruktuur wat die ontwerp en implementering van beplanning- en beheersisteme beïnvloed word bespreek. Die rol van organisasiestruktuur, beplanningsisteme en beheersisteme in organisasie en die onderlinge wisselwerking daarvan word aangetoon en die spektrum van beplanning en beheer word bespreek in terme van Anthony se model, met 'n ontleding van die koppelvlakke tussen organisasiestruktuur, strategiese beplanning, bestuursbeheer en bedryfsbeheer. Strukturele determinante van spesialisasie, verantwoordelikheid, bestuurshiërargie, gesag en finansiële stelsels word ontleed en daar word beskryf hoe elk op een of ander manier die aard van beplanning- en beheersisteme voorskryf. Organisasie-groei, en die uitwerking daarvan op die nodige veranderinge in organisasiestruktuur en beplanning-en beheerstelsels word aangedui; en daar word kortliks op die steriele aard van organisasiestruktuur en beplanning- en beheerstelsels, sowel as die uitwerking van menslike gedrag op organisasie-prestasie, gedui.

S.-Afr. Tydskr. Bodryts! 1979, 10: 1-10

M.D. Groch

Senior Lecturer, School of Business Leadership,

University of South Africa,

P.O. Box 392, Pretoria 0001

\section{Role of organization structure and planning and control systems in organizations \\ Organization structure}

The role of the organization structure is best described in terms of its purpose, which is to ensure that the behaviour of the people that comprise the organization is goal directed. It is in fact management's prescription of the most effective arrangement of the many activities within the organization.

In the early stages of organization development simple structures are adequate for this purpose. The few people employed to undertake the tasks necessary for goal attainment, together with the concentration of authority and decision-making responsibility, result in informal rather than formalized relationships between people in the organization.

Organization growth occurs as the organization expands its domain. As its interests expand there is a marked increase in pressure and strain on its existing capacities. This is particularly the case with human resource as the task skills of the decision-makers in the organization are stretched beyond reasonable limits and the availability of time sufficient to execute duties is at a premium. The result of this state of affairs is increased inefficiencies and with this, reduced effectiveness.

Additional capacity is obtained as more people are absorbed into the organization, as decision-making is decentralized and facilities are extended. The first evidence of specialization is usually encountered during this phase of organization development.

In order to improve efficiency, individuals with specialist skills in marketing, production, engineering and so on are employed and clustered together in groups of like skills and disciplines. In this process increased formalization of the relationships between organizational positions of necessity occurs, in terms of a formal organization structure. The coordination of the behaviour of the various specialist groups becomes of prime importance and the organization structure the prime means for ensuring it.

Thompson ${ }^{1}$ describes the development of organization structure in terms of his differentiation (specialization) and coordination (integration) theory, which has some useful concepts for this paper. Thompson (cited by Lorsch \& Lawrence) assumes that (organization) structure is a fundamental vehicle by which organizations achieve bounded 
rationality. By delimiting responsibilities and control over resources and other matters, organizations provide their participating members with boundaries within which efficiency may be a reasonable expectation. These spheres of bounded rationality are inderdependent in one or more of three ways:

\section{- Pooled interdependence}

- Sequential interdependence and

- Reciprocal interdependence.

The three types of interdependence contain increasing degrees of contingency, moving from pooled to sequential to reciprocal, and for this reason, Thompson postulates, become increasingly more costly to coordinate.

The most appropriate coordinating mechanisms for the three types of interdependence are as follows:

- Coordination by standardization in the case of pooled interdependence

- Coordination by plan in the case of sequential interdependence, and

- Coordination by mutual adjustment in the case of reciprocal interdependence.

Thus, to reduce the cost of coordination, an organization should give first priority to grouping (positions) so as to mimimize the more costly forms of coordination. Thus reciprocally interdependent positions should be clustered together, then sequentially interdependent positions should be clustered together and finally, third priority is given to the grouping of homogeneous positions with pooled interdependence tangent to one another. First order grouping may be inadequate to deal satisfactorily with all forms of interdependence. Thus, organizations should link the groups involved into second- and third-order groups, resulting in an organization hierarchy. Other coordinating mechanisms such as liaison positions (product managers), committees and task forces are formed to achieve coordination in instances where the hierarchy is deficient.

Clearly efficient and coordinated goal directed behaviour is achieved through organization structure only if the information requirements necessary for managing behaviour is provided timeously, in the right form and to the right organization position. Planning and control systems are evolved to supply information neccessary for this purpose.

The purpose of this article is to show the interrelationship between organization structure and these systems, and how the former influences the design and implementation of the latter.

\section{Planning systems}

Every organization plans to a greater or lesser extent. Whether this occurs informally, in the minds of a few managers, or formally as a result of the efforts and contributions from a great number of people throughout the organization, it is clear that there is a perceived need to plan. What is, however, less evident is the existence of effective planning within organizations. This is partly due to the difficulties encountered in the process of planning, to an absence of commitment to this most important activity from the very people who should actively support this function, and to the absence of a satisfactory system of planning to direct managers in this task.

To state that effective planning is essential for organiz- ational survival is to state the obvious. Factors both external and internal to the organization ensure the validity of this proposition. For example, environmental influences such as the acceleration in the rate of technological and social change, increased complexity in the relationship between the organization and the environment, and increased interdependence among organizations, to name but a few, provide threats and opportunities to every organization. If these are ignored organizational survival is jeopardized.

Other factors internal to the organization, that may threaten its existence, each of which influences the need for effective planning can be identified and include such items as:

- Increased organization size with the ensuing communication and coordination problems

- The need to give the organization a direction and to counter dysfunctional behaviour, and

- The need to support the emerging professional manager in his task of striving for improved efficiencies and greater organizational effectiveness.

Many organizations cite these very factors, that make formalized planning essential, as the reasons why it is a waste of effort and thus unnecessary to plan. This view cannot be reconciled with recent developments in commerce and industry. There is ample evidence of the results of ineffective (or no) planning in the number of organizations that have collapsed during the recent economic recession. On the other hand, there is also evidence of some organizations that have survived and grown during the same period, where these improvements can be directly attributed to effective planning.

Planning is seen as the process by which the individuals in the organization decide in advance on some future course of action. Drucker ${ }^{3}$, who supports the earlier views, states that it is the futurity of present decisions and actions, together with the uncertainty of that future, that makes planning essential. To hold the view that this inability to predict the future makes formalized planning an impractical, and thus unncessary, exercise is clearly unfounded.

Planning then is the continuous process of making present entrepreneurial (risk-taking) decisions systematically and with the best possible knowledge of their futurity and organising systematically the efforts needed to carry out these decisions'. ${ }^{3}$

Planning systems must provide information to the managers who are expected to take these decisions, in the form of expectations of the most likely state of the future and how this will influence the outcomes of these decisions, and to those who are required to implement these decisions, in the form of information from management to direct their behaviour towards goal attainment.

The uncertainty that the future holds for organizations demands that this be a continuous and dynamic process in the face of the changing environment within which the organization functions. To continue with Drucker's view the process of planning includes 'measuring the results of these decisions against expectations through organized, systematic feedback'. 


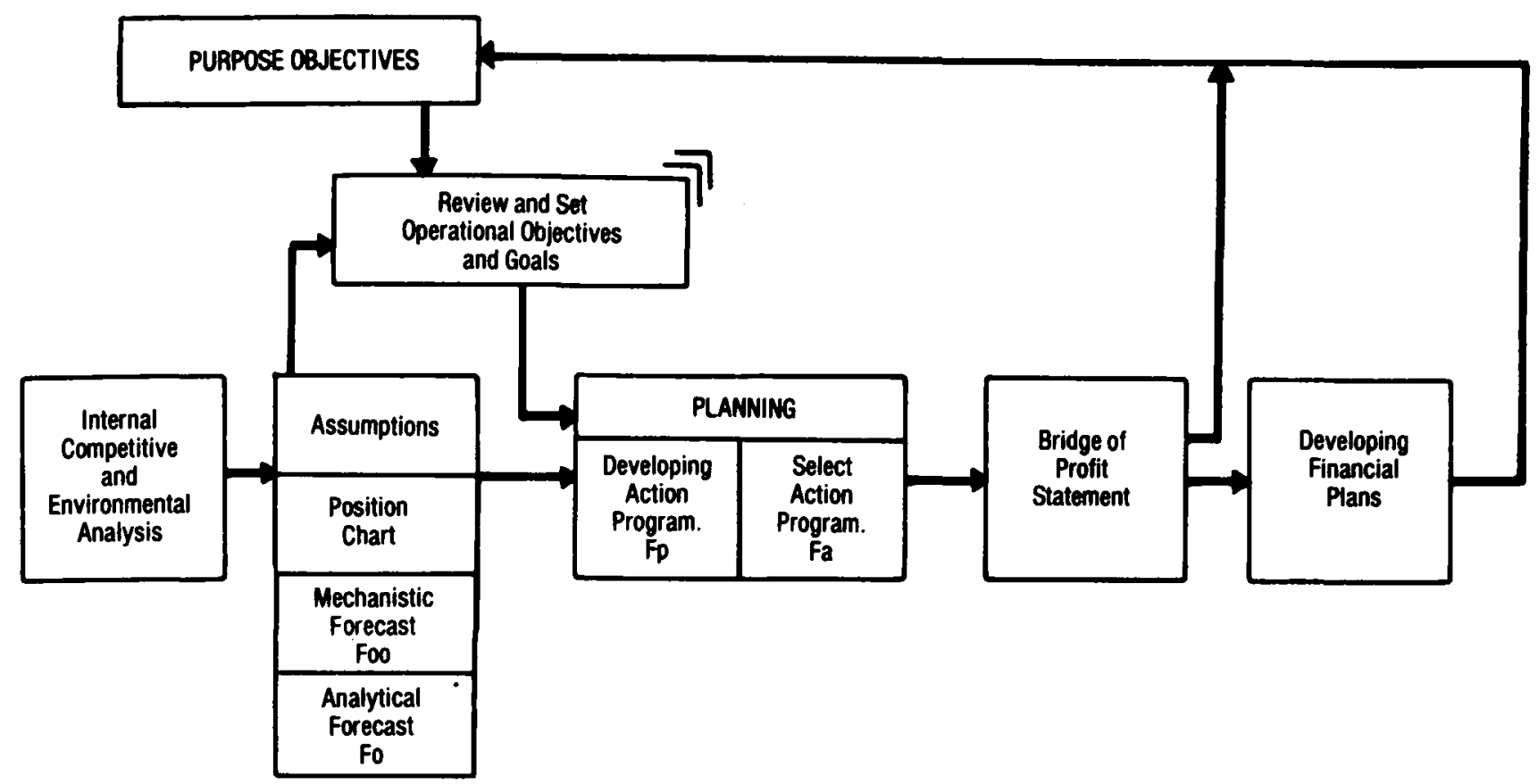

Fif 1 The Management planning process

Control and planning are inextricably linked and to treat them as independent activities is to reduce the effectiveness of both. This statement will be developed further during this discussion. Suffice it to say at this stage that under these circumstances, the process described cannot be a once a year activity, nor can the output from the planning system, be it the organization's profit plan or budget, be stored, gathering dust in some executives' desks.

Schutte's ${ }^{4}$ model of a planning system incorporates all these requirements as illustrated in Fig. 1.

\section{Control systems}

The role of control systems is best described in terms of the approach adopted by $\mathrm{Emch}^{5}$. All persons involved in the organization's activities should know that their responsibilities are and have the necessary information available to carry these out effectively. Control $^{6}$ is seen as the making of decisions and the implementation of these through action required by the responsibilities of an organizational position.

Control and organizational structure are thus inseparable in effective management. This question will be expanded on later but it is worth bearing in mind during the remainder of this article. This view of control is not inconsistent with that held traditionally, which is that control is in fact the assurance, through corrective action, that actual results conform to desired results. This involves the establishing of standards, the measuring of actual results, the comparison of these with the standards and the taking of corrective action to offset unfavourable variances. In Emch's view, each of these components of control, 'must be built into the organization structure as part and parcel of the responsibilities and authorities of each key position' and 'relating control to the specific responsibilities and authorities' is what the process is all about.

Control systems?, in this context, must endeavour to match the responsibilities (and authorities) of every key position in the organization with information necessary for triggering the control process for effective and efficient execution of those responsibilities.

From the above description of the role of planning and control in organizations, it can be concluded that the effective execution of each is dependent on the other, and the systems developed to support these activities clearly do not function in isolation. This fact must be taken into consideration in the design of such systems. Further, organization structure does influence the nature of these systems, the extent and manner of which will now be discussed.

\section{The relationship between organization structure and} the planning and control processes

Within the context of the dynamic organization, different levels of planning and control can be identified and these can be described in many ways. Anthony ${ }^{1}$ in his well-known work on the subject, has classified these into three categories which are strategic planning, management control and technical control (operational control). Because these are easily understood and cover the full spectrum of the planning and control processes, this classification is useful for establishing where organizational structure and planning and control systems are most likely to interfere and interact.

\section{Strategic planning}

'Strategic planning is the process of deciding on changes in the objectives of the organization, in the resources that are to be used in attaining these objectives and in the policies that are to govern the acquisition and use of these resources ${ }^{1}$

Strategic planning decisions are thus concerned with changes in the organization's character and/or its mission.

The input variables to this process include the expectations of the beneficiaries of the organization who determine the purpose objective ${ }^{2}$, the environmental opportunities and threats, internal strengths and weaknesses, and 
the organization's strategic planning gap.

Strategic planning results in changes to the physical, financial and organization structures, policies, procedures and ethos objectives ${ }^{3}$, as well as (higher order) operational objectives of the organization.

The decision by a heavy equipment manufacturer and marketer to discontinue one of its present product ranges; the decision by a human foods company to divest itself of subsidiary companies which had continually performed unprofitably; the research and development organization that decided to change to incorporate a manufacturing division in the face of changing environmental conditions, are some examples of strategic planning decisions.

Clearly then, organization structure is determined by and during the strategic planning process, which is another way of expressing the well-known view that structure follows strategy4.

Management control

'Management control is the process of assuring that resources are obtained and used effectively and efficiently in the accomplishment of the organization's objectives's.

Management control encompasses both the annual planning and budgeting process and the control process aimed at attaining or improving on the operational objectives that are part of the budget. This latter aspect of management control requires continuous monitoring of the performance of the organization, a comparison of the most likely state of the organization at some point in the future, with the required or preferred state of the organization at that time, and a replanning process to optimize the resource conversion process so as to improve on the results directly attributable to organizational momentum. The emphasis is on organizational effectiveness ${ }^{6}$.

Throughout this process, the physical, financial and organizational structures that are employed by the organization interact continuously, and provide the framework within which management control takes place. In this way strategic planning aids and yet constrains management control.

Inputs into the management control process during the annual planning and budgeting phase include:

- The strategic plans of the organization (including the formalized organization structure)

- The (higher order) operational objectives

- An analysis of external (environmental) opportunities and threats and internal strengths and weaknesses in the form of a position analysis and position chart.

- An estimate of the financial results at the end of the planning period due directly to the organization's innate momentum (i.e. Foo and Fo forecasts) ${ }^{7}$ and

- Policies, procedures and other constraints within which managers are required to operate.

Outputs from this process include:

- The operational and financial plans

- (Lower order) operational objectives, goals and standards and

- The possible identification of any strategic planning gap.
During the ensuing period effective, continuous management control requires the following inputs:

- The (lower order) operational objectives

- An updated environmental (position) analysis and position chart

- An updated forecast of the financial results due directly to the organization's momentum with the resultant identification of any operational planning gap (i.e. an updated Foo and Fo forecast compared with the operational objectives) ${ }^{8}$

- The policies, procedures and other organizational constraints and

- The physical, financial and organization structures of the organization, which are determined during the strategic planning process.

Outputs from continuous management control include:

- Updated plans (action programmes) aimed at maximizing the probability of attaining operational objectives

- Revised (lower order) operational objectives, goals and standards, and

- Idenfification of any strategic planning gap that is manifesting itself.

An example of continuous management control of this form is found in an animal foods and feeds company. Having identified a gap between the expected year-end profits and the operational objectives by top management, the sales manager in one of the company's regions, developed and implemented an action programme to improve these results. Instead of purely marketing the company's animal feeds in the agricultural market, the company now operates its own facilities for fattening stock, either on a contract basis from farmers or else by acquiring low grade, low cost stock for fattening and reselling these at a profit. The financial impact of this plan has made a significant contribution to the company's profits and has enhanced the probability of attainment of the operational objectives.

\section{Technical control}

'Technical control is the process of assuring the efficient acquisition and use of resources, with respect to activities for which the optimum relationship between outputs and resources can approximately be determined'.

Technical, or operational control, requires an environment characterized by bounded rationality ${ }^{10}$. It occurs at the technical core of the organization. The emphasis is on efficiency rather than effectiveness and the process is usually described in terms of the black box model which is shown in Fig 2.

As inputs into the process, the following are required:

- Specifications of the physical process of resource conversion

- Specification of the resources themselves, and

- The most desirable outputs (in the form of standards).

Actual results compared with these standards and if deviations are encountered wether the mix between inputs is changed or the conversion process itself is brought into line. 
Table 1 Inputs, Process, Outputs Inputs
(a) Purpose objective
(b) Position analysis
(c) Position chart
(d) Strategic planning gap

(a) Strategic plan

(b) (Higher order) Operational objectives

(c) Position analysis

(d) Position chart

(e) Environmental assumptions

(f) Financial momentum

(g) Policies and procedures

(a)-(g) As for above

I

(h) Operational and financial plans

(a) Specifications

- Resources

- Physical processes

(b) Standards and goals

(c) Policies and procedures

Strategic Planning, Management Planning and Control, and Operations Control

Budgetary control, quality control, timekeeping and so on are examples of the mechanisms used in technical control. In the foods and feeds company mentioned earlier a sharp increase in the moisture content of milled maize was encountered. Clearly the moisture level of the raw maize was higher than was normally the case and by allowing a longer period for drying out the maize, prior to milling, the quality standards were once again attained and maintained.

Thus it is the technology employed by the organization rather than organizational structure that determines the best method for technical control. If a technical control process is the best for a certain technology, then it is the best whenever the technology is employed, irrespective of the organizational structure.

It is clear that organization structure is the result of strategic planning and provides the framework for all aspects of management control. Operational control systems are only indirectly influenced by organization structure through the management control process. Table I explains in summary the planning and control processes with their relationship to the required inputs and eventual outputs from these processes, and clearly shows the relationship between organization structure and the planning and control processes.

\section{Determinants of organization structure and their influence on the design of planning and control systems}

The formal structure of any organization comprises a network of interacting variables each participating in determining the nature of the structure. Each determinant should be

\section{Outputs}

(a) Strategic plan concerning the

- Physical processes

- Financial structure

- Organization structure

(b) Policies and procedures

(c) (Higher order)

Operational objectives
(a) Operational plans
(b) Financial plan (Budgets)
(c) (Lower order)
Operational objectives, goals and
standards

(d) Strategic planning gap (a) Revised operational plans

(b) Revised financial plans

(c)
(d) As above

(a) An efficient utilization of resources recognised and its effects analysed when designing planning and control systems. The relationship between these structural determinants and planning and control systems will now be discussed.

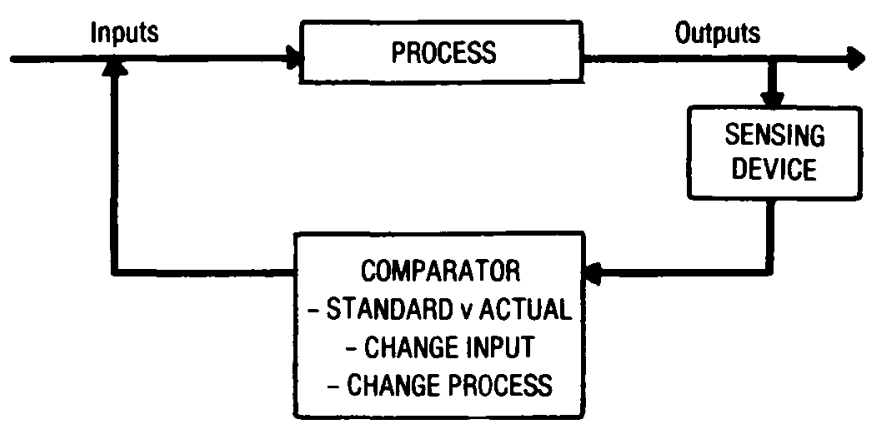

Fig. 2 Operational control process

\section{Specialization}

Some comment has already been made on the occurrence of specialization in organizations and its effect on coordination. The work of Thompson ${ }^{1}$ was used for this purpose.

To be more specific, it is obvious that the type of information necessary for the effective fulfilment of the functions of planning and control within each organization unit

and not to marketing is a ludicrous concept. 
Thus specialization influences the requirements from planning and control systems, of providing the right information, to the right person, at the right time.

Any changes in the form of specialization employed in the organization will result in a change in the requirements from the planning and control systems. Such a change will be the result of a strategic decision, while its effects will be felt in the areas of management control and operational control, therefore the systems required to support these activities will require revision to ensure their effectiveness.

Clearly then the structural determinant, specialization, is influenced by strategic planning and in turn influences management control and indirectly operational control. The extent of specialization in any organization must be taken into account when designing planning and control systems.

\section{Responsibility}

The question of responsibility overlaps and is greatly influenced by the other structural determinants. However, it does determine largely how the organization will function by describing the task requirements of each position in the organization structure as well as its relationship with other organizational positions.

The most generally accepted way in which responsibilities are fomalized is by way of a formal job description. The approaches to the development and description of responsibilities are many, but in practice it has been found that the most effective encountered for reasons of practicality and simplicity is that described by Schutte ${ }^{2}$.

He maintains that responsibilities and hence the roles of positions are usually ill-defined and too broad in their description. By working on the proposition that approximately $20 \%$ of all the tasks undertaken in any position in the organization, result in $80 \%$ of that position's contribution to the financial results of the organization, the incumbent's efforts must be concentrated in these areas of greatest potential contribution. Emphasis must be placed on these areas and the method he adopts is to isolate the 'Key Performance Areas' of each organizational position, where these are the position's unique contribution to the organization's results. The process of identifying these key performance areas is through group discussion, which leads to a clarification of the responsibilities, and specifically the key performance areas of each position in the organization structure. Thus the incumbents of these positions as well as the other people participating in the analysis and discussion, receive a clear prescription of what is expected of them in the position in question. The presence and active participation of top management in the analysis is vital to its success.

Once the responsibilities of each position are clearly identified a number of benefits follow.

In the first place the information necessary to manage, or to operate in terms of the key performance areas and the other responsibilities of the position, is easily identified. The organization's information systems can thus be developed or adapted to provide meaningful and timeous information.

By linking the key performance areas of each organization position to the rewards and discipline systems of the organization, motivation and job satisfaction are likely to follow. This is achieved through a system of regular performance measurement in the key performance areas, which reinforces the noed to emphazie improvement in these areas.
The information necessary for effective control by a superior of his subordinates can be identified by prescribing the yardsticks of satisfactory performance in each key area. This enables the design of control systems, both management control and operational control systems to flow directly from the description of the job's responsibilities.

Change agents (usually in line positions) and the administrators (who are usually in a staff situation) can be separated. This is important to the successful design of planning and control systems, for it is from the change agents, usually a limited number in any organization, that effective management control, for example, is expected. The management control systems must therefore be designed with this in mind. One of the problems encountered in the Massey-Ferguson organization, one of the first companies to approach systems development in this way, was that too many change agents were identified initially. Once this situation was rectified effective management control was achieved.

Finally, job grading, i.e. the relative importance of jobs one to the other, for purposes of salary structure, benefits, promotion paths, etc., can be defined only if the responsibilities, and particularly the key performance areas of each organizational position have been clearly identified.

It is clear that the structural determinant, responsibility, influences systems design and particularly in the area of management control and operational control systems. Once again, a change in strategy, the likely result of effective strategic planning will influence the responsibilities of some positions or add new organizational positions with new responsibilities, so influencing the nature of the management control and operational control systems.

\section{Management hierarchy}

Once again we draw on the work of Thompson ${ }^{3}$ when discussing the structural determinant, management hierarchy. In terms of his differentiation/integration theory a management hierarchy is created when a second order grouping is required to ensure integration (coordination), where the clustering of positions in accordance with their type of interdependencies fails to achieve this. This process can continue until a number of hierachical levels are formed. What is found in practice, however, is that because of structural inefficiencies, redundant managerial positions can occur.

For example, when a key performance area analysis was carried out in a refractory company, one level of managers was proven to be redundant and removed from the management hierarchy. This situation was encountered when duplications of responsibilities in the superior subordinate context were eliminated in the organization, leaving the managerial positions in question with no unique contribution to organizational performance. This example serves to highlight the danger of creating a management hierarchy to cater for improved decision-making, where the decisions being referred up the hierarchy are in fact the responsibility of the lower levels. The solution to this type of structural inefficiency is obviously to clarify the responsibilities of each position in the hierarchy in the manner described earlier and then, should the situation call for such action, remove redundancy immediately.

The management hierarchy influences systems design in 
many ways. Each manager has a certain decision-making responsibility and requires information relevant to those decisions in order to execute this function. If we are concerned with the position of a change agent, this information should be provided by both the management control and operational control systems, while the information necessary for decision-making by the administrative and supervisory staff is likely to be provided by the operational control system. Thus the structural determinant, management hierarchy, must be taken into consideration in designing the management control and operational control systems. Changes in the management hierarchy will of necessity result in changes to these systems. Such changes occur as a result of changes at a strategic level.

Finally, when designing the operational control systems, specific notice should be taken of the danger of an information overload. Since most decisions in any organization are concerned with technical or operational control, it stands to reason that the greatest amount of information flowing in any organization has to do with this activity. Management by exception is a valid technique used to reduce the volume of information reaching successively higher levels in the management hierarchy. Schutte's ${ }^{4}$ exceptions matrix was developed to structure the tolerance levels that are applicable to each level in the hierarchy. These levels of exception are an integral part of any operational control system, which is further evidence of how the management hierarchy influences the design of operational control systems.

\section{Authority}

Each organizational position acquires authority of some form, either formally through the policies and procedures of top management, or informally through the political processes within the organization. The structural determinant, authority, has greatest impact on organizational effectiveness in the formal delegation of authority from the top levels in the management hierarchy down to the lower levels. When the formal authority is incompatible with the responsibilities of a position, either the structure is suboptimum or, depending on the power held by the incumbent of the position, politicking will ensue in striving to ensure a balance between responsibility and authority. The formal delegation of authority to match the responsibility of a position is less likely to result in dysfunctional behaviour and is a more acceptable approach to this question.

Authority affects the design of planning and control systems, since such systems are incomplete without some specification of the various processes that they support. For example, in management control the processes of review, discussion and negotiation, and finally approval of elements such as action programmes and budgets, is integral to the system. Review cycles, the sequence of review meetings and the approval levels (usually expressed in financial terms) are part of the management control system and are determined by the authority held by each organization position.

Similarly, in the case of designing operational control systems, exception levels must be set with authority levels in mind. It is impractical for a superior to set such an exception level too high if the authority delegated to the subordinate requires a greater level of participation by him in the operational control decisions in question.
Authority levels (limits) are, as mentioned, set by the policies and procedures emanating from the strategic planning process of top management. Any changes in strategy should be reflected in these policies and prodecures and will affect the management control and operational control systems. Once again we see how strategic planning establishes the framework for management control systems and subsequently, operational control systems.

\section{Financial systems}

The organization's financial systems are at the core of the management control systems and budgetary control systems, in the area of operational control, and influence the design of these systems. The criteria for establishing financial responsibility are best described in terms of Vancil's ${ }^{8}$ work from which the following quote is drawn.

'The principal types of financial responsibility can be classified as follows: standard cost centres are exemplified by a production department in a factory. The standard quantities of direct labour and materials required for each unit of output are specified. The foreman's objective is to minimise the variance between actual costs and standard

only use its best judgement to set the budget, and the department manager's objective is to spend the budgeted amount to produce the best (they are still unmeasurable) quality of service that he possibly can.

Profit centres are units, such as a product division, where the manager is responsible for the best combination of cost and revenues. His objective is to maximize the bottom line, the profit that results from his decisions. A great many variations on this theme can be achieved by defining 'profit' as including only those elements of cost and revenue for which the manager is responsible. Thus the sales manager who is allowed to set prices may be responsible for growth profit (actual revenue less standard manufacturing cost). Profit for a product line marketing manager, on the other hand, might reflect deductions for budgeted factory overhead and actual sales promotion expenses.

Investment centres are units where the manager is responsible also for the magnitude of assets employed. He makes trade-offs between current profits and investments to increase future profits. Stating the manager's objective as maximizing his return on investment or his residual income (profit after a charge for the use of capital) helps him to appraise the desirability of new investments.'

The form in which information is presented to organizational positions must be compatible with the financial responsibility of that position. In this way the structural determinant, financial systems, determines the design of both 
management control and operational control systems. Finally, the form of financial systems adopted by the organization is the outcome of strategic planning. The relationship between strategic planning, organization structure, and management and operational control systems is established once again.

\section{Organization growth and its effect on organizational structure, and on planning and control systems}

\section{Simple structures}

During the initial stages of an organization's existence simple structures comprising a few people, who clearly understand their responsibilities and limits of authority, suffice to ensure goal attainment. Planning and control is rarely systemized and occurs informally within the management positions of the organization.

Organization growth brings with it the need to specialize. This in turn requires specification of the authority levels and responsibilities for each position in the organization. The management hierarchy evolves to ensure greater effectiveness in coordinating individual efforts and in decisionmaking. Line and staff positions crystallize as change agents and administrators are isolated one from the other. The financial systems take shape in a more sophisticated form with the concepts of cost centres, revenue centres, discretionary expense centres, profit centres and investment centres likely to occur during this phase. The situation is typified by simple functional structures, of which an example is shown in Fig. 3. Two levels of management are required in such an organization structure, the one being the general management requirement straddling the functions, the other being the specialist functional management requirement. Such a functional structure can have various combinations of financial responsibility (performance) criteria.

To quote once again from Vancil ${ }^{8}$

'With just two functional units (manufacturing and marketing), and two alternatives available for each (standard cost and profit centres in the case of manufacturing and revenue and profit centres in the case of marketing), there are still four alternatives for the design of management control systems for this business:

$\begin{array}{lll}\text { Alternative } & \text { Manufacturing } & \text { Marketing } \\ 1 & \text { Standard cost centre } & \text { Revenue centre } \\ 2 & \text { Standard cost centre } & \text { Profit centre } \\ 3 & \text { Profit centre } & \text { Revenue centre } \\ 4 & \text { Profit centre } & \text { Profit centre' }\end{array}$

In this type of structure the general manager alone has investment centre responsibility.

The formalization of planning and control systems becomes a necessity with the structural determinants interacting to influence their most effective design in the manner described earlier. The final form of these systems will be determined for the organization by the strategy adopted by top managers.

Organization growth, with its accompanying pressure on organization structure and the systems employed, is the trigger for change, which, if ignored, increases the probability of organization failure. The result of such growth will be greater complexity in the structure and systems.

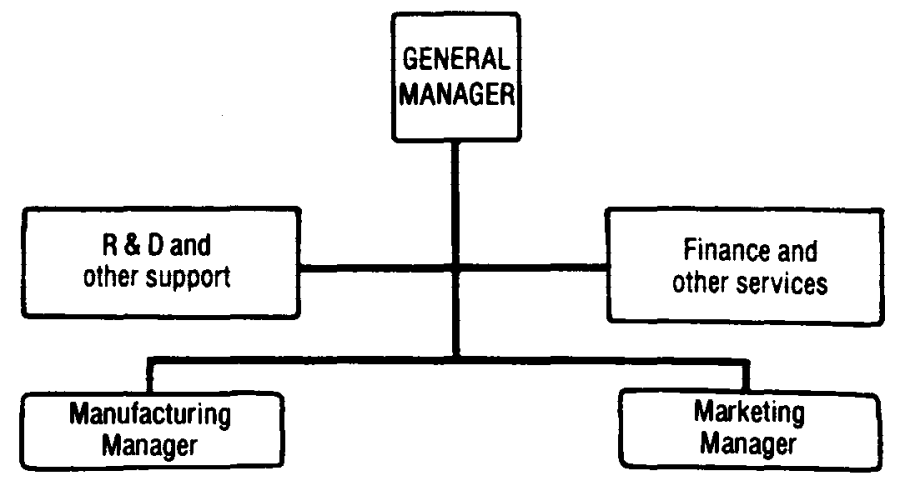

Fig. 3 Simple functioning structure

\section{Complex structures}

The alternative structures available can be categorized in the form of more complex functional structures, such as the example in Fig. 4, or a divisionalized structure, as shown in Fig. 5.

In either of these two alternatives the nature of, and relationship between, the structural determinants become more complex, as do the structures of the planning and control systems.

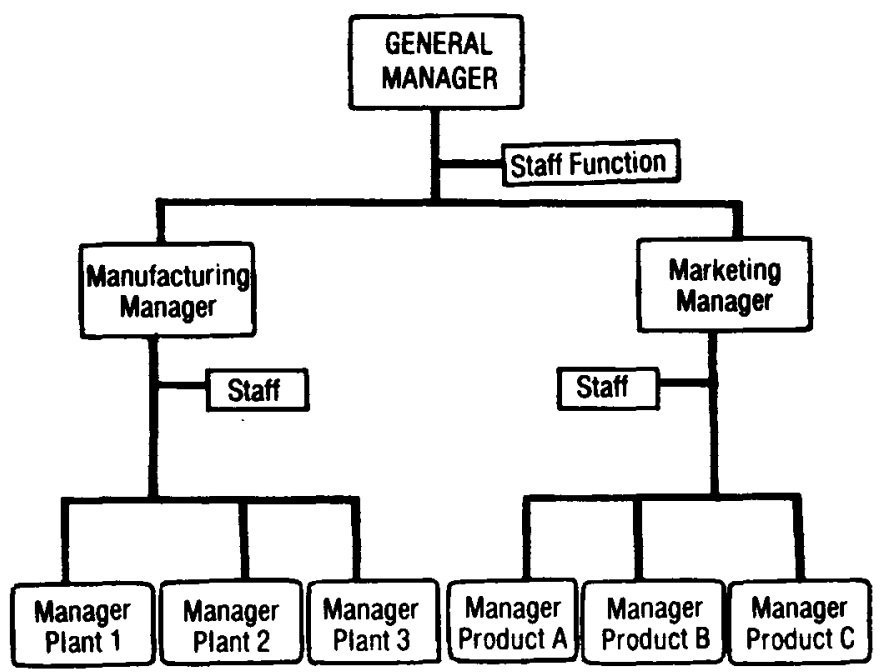

Fig. 4 Complex functioning structure

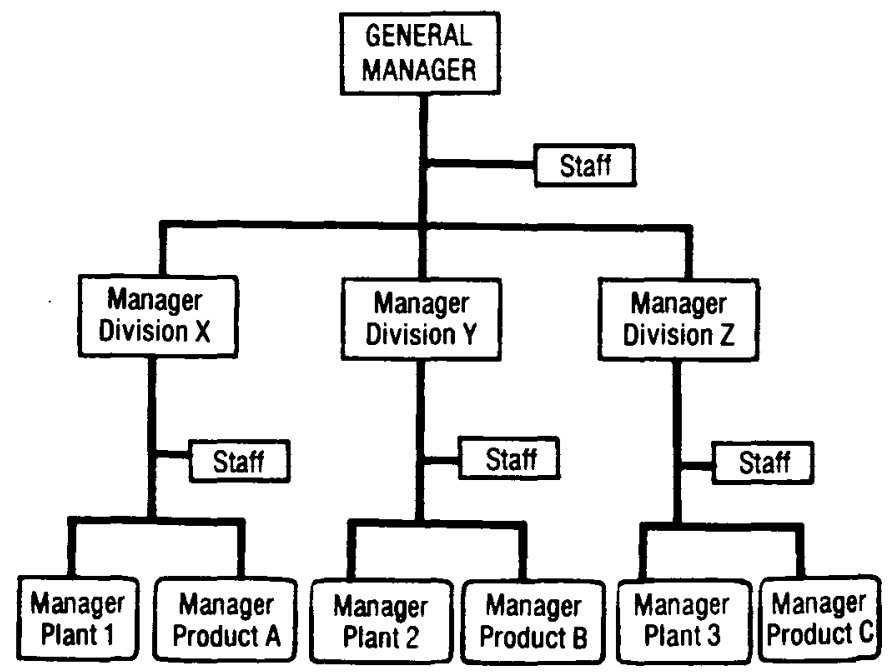

Fig. 5 Complex divisional structure 
There is an increased likelihood of conflict between the authority and responsibilities of the organizational positions. A top-heavy managerial hierarchy, with the likelihood of redundancy with the management levels, may occur. The financial systems of the organization become more complex and decisions are required as to the most desirable form of financial performance criteria for the structure adopted. In the case of the complex functional structure, Vancil suggests little change in the alternatives available, in comparison to the simple functional structures discussed earlier.

For the divisionalized structures, however, the divisions, he suggests, should be treated as investment or profit centres, i.e. as though they were independent companies, with the same criteria as for functional structures pertaining within each division.

Having identified the need or organizational change, the growing company, in selecting which of the two structures to adopt, makes the choice according to whether it seeks greater efficiency which is provided by the functional structure, or whether it seeks to increase its overall effectiveness, the hallmark of a divisionalized structure.

These structures have their own identifiable benefits and the question of choice is resolved in the process of strategic planning. Both these complex structures require revision of planning and control systems employed in the organization. Once again the structural determinants will dictate the final form that these should take.

Attempts to resolve this conflict, i.e. the choice between functional and divisional structures, have led to organizations to adopt matrix structures such as the one depicted in Fig. 6. In matrix structures positions have a dual responsibility in that vertically, they have line or functional responsibility dictated by the specialized nature of the positions' functions. This is of a permanent nature. Horizontally, they have product or programme responsibility, determined by the product or programme requiring the particular specialist skill of the position. Such responsibility is temporary, lasting for the duration of the product or programme's life cycle.

Conflict in this dual arrangement is avoided by adopting the procedure where the functions subcontract in some way the specialist skills they offer to the programme for as long as the skills are required.

Three differing management skills are now identifiable: the general management function, which now spans not only the functions but also the programme requirements; the specialist functional managers, who are responsible for organizational efficiency; and programme or product management, which is charged with organizational effectiveness.

In such structures the authority relationships are particularly interesting, but open to much conflict. Obviously, functional managers acquire their authority in the manner already described by virtue of their position in a direct line situation with the general managers. The authority of programme or product managers is not so easily resolved. They depend largely on the cooperation of the functional managers in the execution of their responsibilities. They should therefore be political animals relying on their skills for manipulating and influencing people to achieve their objectives. Such managers are usually assisted in this task

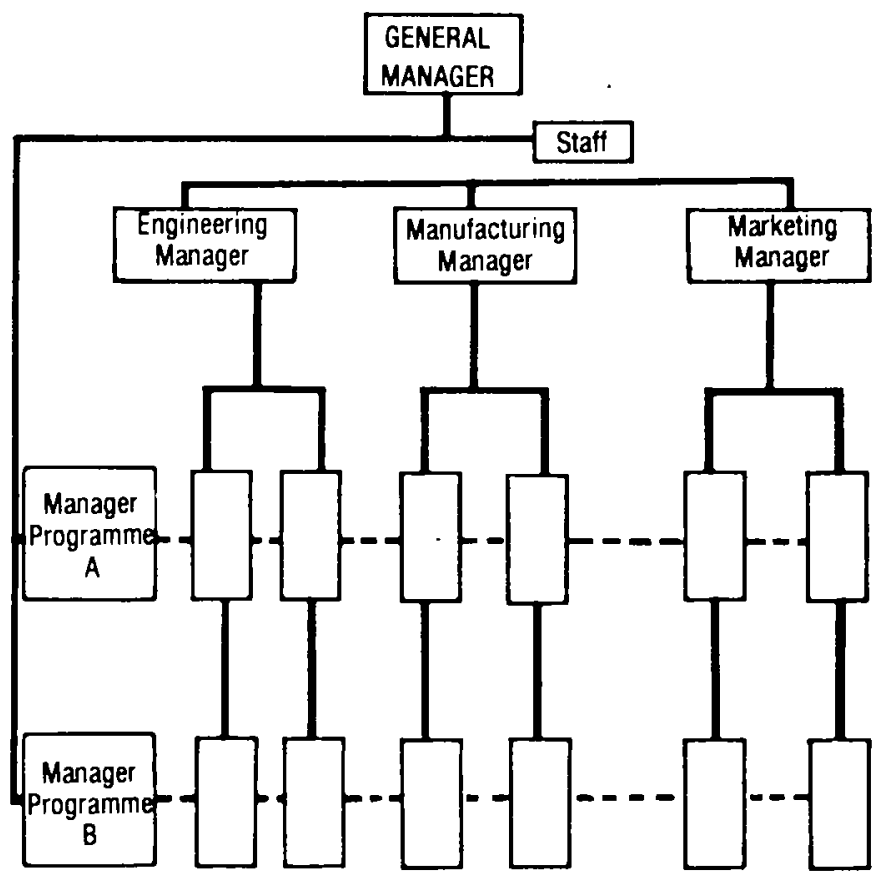

Fig. 6 Matrix organization

by having direct access to the general manager. This is a fundamental requirement of successful matrix structures.

Matrix structures are expensive entities and so best suited to organizations with complex technologies. Examples occur in the weapons systems industry, construction, ship building and research and development, where the products of the organization are comprised of a number of complex subsystems, each requiring different specialist skills.

Depending on the nature of the programme or product, the management hierarchy may consist of a single programme/product manager of a fully-fledged unit (such as a department) which would develop in the same way described earlier.

The financial performance criteria adopted may be any combination of the criteria described by Vancil. In a South African shipbuilding company, organized according to a matrix structure, the functional managers, who are concerned with organizational efficiency, are regarded as cost centres, while the programme managers, who are concerned with organizational effectiveness, are responsible for programme profitability, and considered profit centres. The general manager of this organization is held responsible for return on equity, i.e. he is regarded an an investment centre.

Whatever financial measures are adopted, double counting of each rand of expense or revenue, except for functional or programme overheads, which are direct expenses to each relevant unit, is required.

The management control and operational control systems designed for such a structure embody all the characteristics of the planning and control systems discussed previously and are influenced once again by the structural determinants according to how these are set by top management through the strategic planning activity. Once again, any change to any of these structural determinants will necessitate changes to these planning and control systems. 


\section{Conclusion}

The impression may have been given that the thoughts presented are too simplistic for practical use. This has been purposefully done for the reason that, to treat such a complex subject in any other way, would have reduced this work to something bordering on chaos.

Clearly the relationship between strategic planning, management control and operational control is neither as simple nor clear cut as either Anthony maintains or as is held in the foregoing. Similarly the effects of any of the structural determinants on the design of systems to support these management activities, do not occur in isolation from the effects of any other structural determinant. Their interaction is complex and multiple. Finally, organization growth does not result in a systematic approach by management to changes in organization structure. In fact, commerce and industry abound with organizations with less than optimum structures, which are yet apparently profitable.

By simplifying the discussion in the manner chosen, the author hoped to cover, in a meaningful way, the task at hand. Showing the interfaces among the activities of strategic planning, management control and operational control, by isolating and analysing these in terms of the effect of the identified structural determinants, has served to indicate that the organization structure does influence the design, and implementation, of planning and control systems. To treat these independently and separately from one another is to run the risk of both ineffective structures and systems.

Finally, the formal organization structure and the management systems employed in an organization to ensure its effectiveness and efficiency, are passive. It is the people employed in the organization that determine its performance as a dynamic entity. Management styles, task and people skills, political action and other behavioural aspects of the employees of the organization, from top management to the lowest operator, dictate the organization's character, success or failure. By introducing human aspects into the above discussion, the complexity will be magnified and the subject taken beyond the confines of this article. Suffice it to say that to ignore the human aspect in both organization and systems design is to reduce each to a clinical exercise unlikely of successful implementation.
7 SCHUTTE, F.G. Increasing Effectiveness by Group Discussion and Participation. GBPDLO 2 University of South Africa p 73-78.

8 VANCIL, R.F. 1973. What kind of Management Control do you need? Harvard Business Review. September p 75-86.

9 ANTHONY, R.N. 1964. Planning and Control Systems: A framework for analysis. Management Services I. March-April p 18-24.

\section{Roferences}

1 THOMPSON, J.D. 1967. Organizations in Action, McGraw-Hill, Inc. p 51-65.

2 LORSCH, J.W. LAWRENCE 1972. Organization Planning: Cases and Concepts, Richard D. Irwin, Inc. \& The Dorsey Press. p 32-37.

3 DRUCKER, P.F. 1959. Long-range Planning: Challenge to Management Science. Management Science V, p 238-249.

4 SCHUTTE, F.G. 1977. Control and Control System: QMP/04. University of South Africa.

5 EMCH, A.F. 1954. In today's business more than ever control means action and the part of every key incentive. Harvard Business Review July/August p 92-98.

6 SCHUTTE, F.G. 1977. Planning and Planning Systems: QMP/03. University of South Africa. 